\title{
An Asymmetric Synthesis of Lactones from Cyclic Acid Anhydrides with Chiral Binaphthyldiamines ${ }^{1)}$
}

\author{
Yukio Kawakami, Jun Hiratake, Yukio Yamamoto \\ and Jun'ichi ODA* \\ Institute for Chemical Research, Kyoto University, \\ Uji. Kyoto 611, Japan
}

Received September 25, 1985

\begin{abstract}
Asymmetric ring opening of the cyclic acid anhydrides $c i s-2,3 \sim 6$ with the axially dissymmetric binaphthyldiamines $(S)$-1a $\sim \mathbf{d}$ and subsequent esterification gave diastereoisomeric mixtures of the amide-esters $\mathbf{7} \mathbf{a} \sim \mathbf{h}$. Successive reduction of the ester group and ring closure by hydrolysis afforded (-)-cis-2,4-dimethyl- $\delta$-valerolactone $(8,92 \%$ e.e.), (-)-mevalonolactone $(9,58 \%$ e.e.), (+)-3isopropyl- $\delta$-valerolactone $(10,42 \%$ e.e. $)$, and (+)-2,3-methylene- $\gamma$-butyrolactone $(11,46 \%$ e.e. $)$. Through kinetic resolution of the racemic anhydride trans-2, (-)-trans-2,4-dimethyl- $\delta$ valerolactone (12) was yielded in a $74 \%$ e.e., whose absolute configuration was established to be $2 R, 4 R$.
\end{abstract}

Among various types of asymmetric reactions, it is an effective method to prepare optically active products from symmetrical molecules. ${ }^{2)}$ From this viewpoint, dehydrogenases $^{3)}$ and esterases ${ }^{4)}$ have been used for the discrimination between enantiotopic groups, and optically active lactones were prepared by subsequent chemical conversion. As a nonenzymatic counterpart, selective acyl-substitution has been successfully performed in which active amides with a chiral leaving group were employed. ${ }^{5)}$ Asymmetric syntheses of lactones based on the discrimination have also been effected by chemical oxidation and reduction. ${ }^{6)}$

It has been reported that diastereoisomeric mixtures of a half-amide and a half-ester were formed with low selectivity by treating cyclic acid anhydrides with a chiral amine ${ }^{7)}$ and a chiral alcohol, ${ }^{8)}$ respectively. However, if the selectivity could be improved by choosing appropriate nucleophiles, the reaction might be a promising candidate for enantiotopic group differentiation. ${ }^{9)}$ Because an axially dissymmetric structure was considered to be

\footnotetext{
* To whom correspondence should be addressed.
}

suitable for the selection, we chose $(S)-\left[1,1^{\prime}\right.$ binaphthyl]-2,2'-diamine $(\mathbf{1 a})^{10,11)}$ as an axially dissymmetric parent compound. We also attempted to elaborate the chiral nucleophile for exhibiting high selectivity through acylation or alkylation of one of the two amino groups in 1a.

Selective monoacylation of $\mathbf{1 a}$ with trifluoroacetic anhydride provided the trifluoroacetyl derivative $\mathbf{1 b}$ in a $67 \%$ yield. The piperidino derivative 1c was afforded in a $38 \%$ yield by reductive $N$-alkylation with glutaraldehyde and sodium cyanoborohydride. A one-pot synthesis through ozonolysis of 2,5-dihydrofuran and subsequent reductive $N$-alkylation gave the morpholino derivative $1 d$ in a $42 \%$ yield. ${ }^{12}$ ) Taking account of naturally occuring lactones or the analogs, the prochiral acid anhydrides $\mathbf{2} \sim \mathbf{6}$ were subjected to the present asymmetric synthesis.

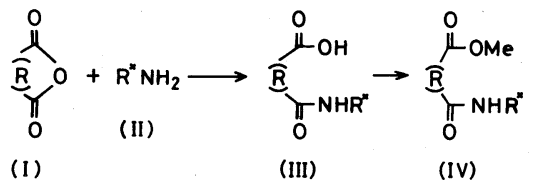

SCHEME 1. Asymmetric Ring Opening of Cyclic Acid Anhydrides with Chiral Amines. 


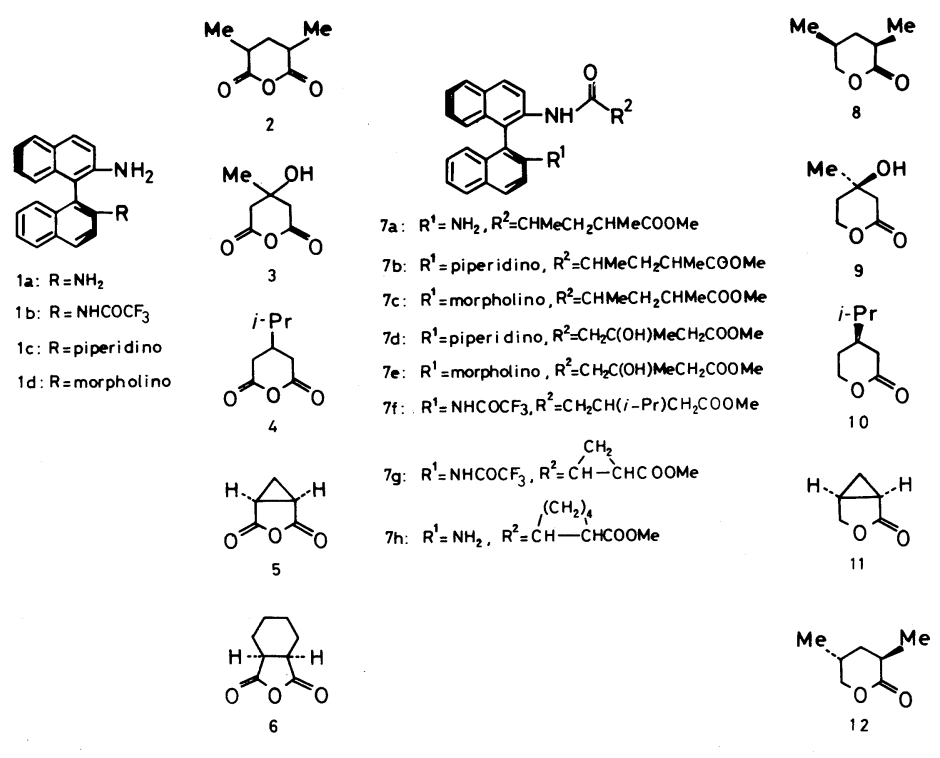

Scheme 2. Chiral Amines, Acid Anhydrides, Amide-esters and Lactones.

The stereoselectivity of the asymmetric ring opening was assessed on the diastereoisomeric ratios of the amide-esters (IV) by HPLC (Scheme 1). A preliminary examination of the selectivity on (IV) revealed that it was not always satisfactory in every combination of the acid anhydrides (I) and the amines (II). However, the selectivity was particularly high in several cases (Table I).

Based on these observations, optically active cis-2,4-dimethyl- $\delta$-valerolactone (8) was synthesized. An equimolar amount of cis-2,4-dimethylglutaric anhydride $(\text { cis-2 })^{13)}$ reacted with 1c to give the half-amide. After treatment with diazomethane, the diastereoisomeric ratio in the resulting amide-ester $\mathbf{7 b}$ was determined by HPLC (Table I, run 2). The amide-ester $\mathbf{7 b}$ was subjected to selective reduction of the ester group by lithium borohydride. Hydrolysis then gave $(-)-(2 R, 4 S)$-cis-2,4-dimethyl- $\delta$ valerolactone $(\mathbf{8})^{14)}$ in an overall yield of $77 \%$ from cis-2. The optical purity was $92 \%$ based on the maximum rotation which coincided with the diastereoisomeric ratio in $\mathbf{7 b}$. The diastereoisomers of 7a from cis-2 and 1a were separated from each other by silica gel chromatography (Table I, run 1). The major isomer of 7a was $N$-acetylated and then sub- jected to successive reduction and hydrolysis as earlier mentioned to afford optically pure $(-)-8$.

Stereoselection was moderate in 3-hydroxy3-methylglutaric anhydride (3), ${ }^{15)}$ 3-isopropylglutaric anhydride (4), ${ }^{16)}$ and 1,2-cyclopropanedicarboxylic anhydride $(5)^{17)}$ (Table I, run $4 \sim 7$ ). Successive reduction and hydrolysis of $7 \mathbf{e}, 7 \mathbf{f}$ and $7 \mathrm{~g}$ as described for $7 \mathbf{b}$ afforded $(-)-(R)$-mevalonolactone $(9,58 \%$ e.e. run 5$), \quad(+)-(R)$-3-isopropyl- $\delta$-valerolactone $(10,42 \%$ e.e. run 6$)$ and $(+)-(2 R, 3 S)-2,3-$ methylene- $\gamma$-butyrolactone $(11,46 \%$ e.e. run 7$)$, respectively. Because the rotatory method for determining the enantiomeric excess (e.e.) of 9 has been reported to be unreliable, ${ }^{18)}$ it was determined by using a chiral shift reagent, and was somewhat lower than the value expected from the diastereoisomeric ratio in 7 e (run 5). This may have been due to partial racemization during the isolation process. As expected from the separation factor of $7 \mathbf{f}$ $(\alpha=1.22)$, the chromatographic separation of each diastereoisomer was successfully performed. The stereochemical outcome showed that the pro- $R$ carbonyl group was preferentially attacked in the reactions. The selectivity of the reaction with cis-1,2-cyclohexane- 
Table I. Asymmetric Synthesis of Lactones through Differentiation between ENANTIOTOPIC GROUPS OR ENANTIOMERS

\begin{tabular}{|c|c|c|c|c|c|c|c|c|c|c|}
\hline \multirow[b]{2}{*}{ Run } & \multirow{2}{*}{$\begin{array}{c}\text { Acid } \\
\text { anhydride }\end{array}$} & \multirow[b]{2}{*}{ Amine } & \multicolumn{3}{|c|}{ Amide-ester } & \multicolumn{5}{|c|}{ Lactone } \\
\hline & & & Compound & Ratio & $\alpha^{b}$ & Compound & $\begin{array}{l}\text { Yield } \\
(\%)\end{array}$ & Config. & {$[\alpha]_{\mathrm{D}}$} & e.e. \\
\hline 1 & $c i s-2$ & $1 \mathbf{a}$ & $7 a$ & $20: 80$ & $1.40^{c}$ & & & & & \\
\hline 2 & cis-2 & $1 c$ & $7 b$ & $4: 96$ & $1.05^{d}$ & 8 & 77 & $2 R, 4 S$ & $-37.8^{\circ i}$ & 92 \\
\hline 3 & cis-2 & 1d & $7 \mathrm{c}$ & $10: 90$ & $1.39^{e}$ & & & & & \\
\hline 4 & 3 & 1c & $7 d$ & $20: 80$ & $1.17^{f}$ & & & & & \\
\hline 5 & 3 & 1d & $7 e$ & $17: 83$ & $1.16^{f}$ & 9 & 44 & $R$ & $-12.2^{\circ j}$ & 58 \\
\hline 6 & 4 & $1 b$ & $7 f$ & $79: 21^{a}$ & $1.22^{g}$ & 10 & 38 & $R$ & $+7.1^{\circ k}$ & 42 \\
\hline 7 & 5 & $1 b$ & $7 g$ & $29: 71$ & $1.06^{g}$ & 11 & 65 & $2 R, 3 S$ & $+28.0^{\circ l}$ & 46 \\
\hline 8 & 6 & $1 \mathbf{a}$ & $7 \mathrm{~h}$ & $38: 62$ & $1.40^{c}$ & & & & & \\
\hline 9 & trans-2 & $1 \mathrm{c}$ & $7 b$ & $87: 13$ & $1.20^{d}$ & 12 & 47 & $2 R, 4 R$ & $-60.1^{\circ}$ & 74 \\
\hline 10 & trans-2 & 1d & $7 c$ & - & h & 12 & 41 & $2 R, 4 R$ & $-53.4^{\circ}$ & 66 \\
\hline
\end{tabular}

a This was the best ratio in several experiments and does not coincide with the e.e. of $\mathbf{1 0}$ that was actually synthesized.

$b$ Separation factor.

c Ethyl acetate-hexane-triethylamine $=1: 2: 0.03,3 \mathrm{ml} / \mathrm{min}$.

${ }^{d}$ Ethyl acetate-hexane-triethylamine $=1: 7.5: 0.05,3 \mathrm{ml} / \mathrm{min}$.

$e$ Ethyl acetate-hexane-triethylamine $=1: 4: 0.05,3 \mathrm{ml} / \mathrm{min}$.

$f$ Hexane-2-propanol-triethylamine $=20: 1: 0.2,0.4 \mathrm{ml} / \mathrm{min}$.

$g$ Ethyl acetate-hexane-triethylamine $=2: 3: 0.05,3 \mathrm{ml} / \mathrm{min}$.

$h$ HPLC separation was incomplete for assessing the ratio.

i $[\alpha]_{\mathrm{D} \max }^{25}-41.1^{\circ}\left(\mathrm{CHCl}_{3}\right)$; C.-S. Chen, Y. Fujimoto and C. J. Sih, J. Am. Chem. Soc., 103, 3580 (1981).

$j \quad[\alpha]_{\mathrm{D} \max }^{20}-23.0^{\circ}(c=6, \mathrm{EtOH}) ; \mathrm{R} . \mathrm{H}$. Cornforth, J. W. Cornforth and G. Popják, Tetrahedron, 18, 1351 (1962).

${ }^{k}[\alpha]_{D \max }+16.9^{\circ}(c=1.037$, EtOH); G. Yabuya and K. Mori, Nippon Nôgeikagaku Kaishi, 56, 1121 (1982).

l $[\alpha]_{D \max }+61.8^{\circ}\left(c=6.6, \mathrm{CHCl}_{3}\right)$; I. J. Jakovac, G. Ng, K. P. Lok and J. B. Jones, J. Chem. Soc., Chem. Commun., 515 (1980).

dicarboxylic anhydride (6) was low, but chromatographic separation of $\mathbf{7 h}$ was also successful $(\alpha=1.40)$.

The piperidino derivative 1c reacted with a five-fold excess of racemic 2,4-dimethylglutaric anhydride (trans-2). The stereoselectivity of this kinetic resolution was evaluated on the ratio of $7 \mathbf{b}$ (Table I, run 9). ${ }^{19)}$ In the same manner as that for the cis-isomer $\mathbf{8},(-)$ trans-2,4-dimethyl- $\delta$-valerolactone $\mathbf{1 2}$ with $[\alpha]_{\mathrm{D}}-60.1^{\circ}$ was obtained in an overall yield of $47 \%$ from 1c. The e.e. of 12 was calculated to be $74 \%$ from the diastereoisomeric ratio in $\mathbf{7 b}$. Using $\mathbf{1 d}, \mathbf{1 2}$ with $[\alpha]_{\mathrm{D}}-53.4^{\circ}$ was also synthesized, whose e.e. was determined to be $66 \%$ by a comparison of the specific rotations of 12 (run 9, 10). The absolute configuration of (-)-12 was established by the chiroptical method, a simple comparison of its CD spectrum with those of $(-)-8$ and
Table II. CD MaXima of the Optically Active 2-Methylated $\delta$-VAlerolactones

\begin{tabular}{lccc}
\hline & \multicolumn{2}{c}{ Ellipticity $^{a}$} \\
\cline { 3 - 4 } Lactone & {$[\alpha]_{\mathrm{D}}$} & $\begin{array}{c}{[\theta]} \\
\left(\mathrm{deg} \cdot \mathrm{cm}^{2} \cdot \mathrm{dmol}^{-1}\right)\end{array}$ & $(\mathrm{nm})$ \\
& & -2930 & 221 \\
& & -1550 & 227 \\
$2 R, 4 R-\mathbf{1 2}$ & $-53.4^{\circ}$ & -3910 & 225 \\
$2 R, 4 S-8$ & $-21.8^{\circ}$ & $-40.7^{\circ}$ & \\
\hline
\end{tabular}

a Measured in hexane.

$b$ The data were reported in the literature. A. I. Meyers, Y. Yamamoto, E. D. Mihelich, and R. A. Bell, J. Org. Chem., 45, 2792 (1980).

$(R)$-( - )-2-methyl- $\delta$-valerolactone (13) suggesting the $2 R, 4 R$ configuration of $(-)-\mathbf{1 2}$ (Table II). This conclusion was confirmed by the lactone chirality rule which correlated the Cotton effect with the dihedral angle around the ester group. ${ }^{20}$ ) The conformation (A) pre- 


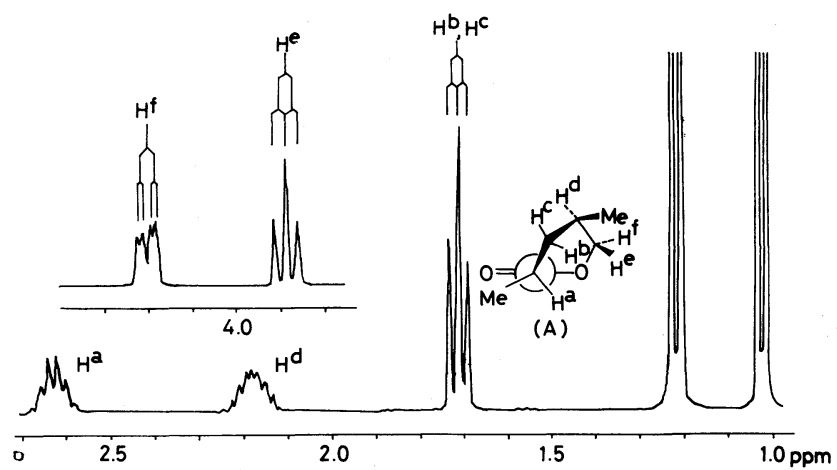

FIG. 1. ${ }^{1} \mathrm{H}$ NMR Spectrum $(400 \mathrm{MHz})$ of trans-2,4-Dimethyl- $\delta$-valerolactone (12) in $\mathrm{CDCl}_{3}-\mathrm{CCl}_{4}(1: 2)$.

dicted by ${ }^{1} \mathrm{H}$ NMR spectroscopy $(400 \mathrm{MHz}$, Fig. 1) and the negative maximum at $221 \mathrm{~nm}$ in its $\mathrm{CD}$ spectrum also indicated the $2 R, 4 R$ configuration of (-)-12. Accordingly, it was the $2 R, 4 R$-enantiomer of trans-2 that reacted preferentially with $\mathbf{1 c}$ and $\mathbf{1 d}$.

\section{EXPERIMENTAL}

IR spectra were recorded with a Hitachi 215 spectrometer, and ${ }^{1} \mathrm{H}$ NMR spectra were measured in deuterochloroform with Varian EM-360 (60 MHz), JEOL FX-100 (100 MHz) and GX-400 (400 MHz) spectrometers. Mass spectra were recorded with a JEOL JMS-DX-300, and optical rotations were measured with a Perkin-Elmer R-241 polarimeter. A Jasco Model J-20 spectropolarimeter was employed for CD spectra. HPLC analyses were carried out on a Jasco BIP-1 chromatograph system equipped with a silica gel column (NUCLEOSIL 50-5, $4 \mathrm{~mm} \times 25 \mathrm{~cm})$. GLC analysis was performed on a Shimadzu GC-4CM gas chromatograph $(4 \mathrm{~mm} \times 1 \mathrm{~m}$ column, 5\% XE-60). A Varian Aerograph Model 920 gas chromatograph $\left(1 / 4^{\prime \prime} \times 1 \mathrm{~m}\right.$ column, $10 \%$ SE-30) was used for preparative GLC. $(S)-(-)-\left[1,1^{\prime}\right.$-Binaphthyl]-2,2'-diamine $\left[1 \mathrm{a}[\alpha]_{\mathrm{D}}^{25}-151.5^{\circ}(c=1.47\right.$, pyridine $)$; lit., $[\alpha]_{\mathrm{D}}$ $-149.5^{\circ}$ ] was prepared according to the literature. ${ }^{10)}$

Preparation of the trifluoroacetyl derivative $\mathbf{1 b}$. Trifluoroacetic anhydride $(1.62 \mathrm{~g}, 7.7 \mathrm{mmol})$ was added to a mixture of $1 \mathrm{a}(2.0 \mathrm{~g}, 7.0 \mathrm{mmol})$, trifluoroacetic acid $(5.4 \mathrm{ml})$ and $\mathrm{CH}_{2} \mathrm{Cl}_{2}(10 \mathrm{ml})$ with ice-cooling. The mixture was stirred at room temperature overnight and poured into sat. $\mathrm{NaHCO}_{3}(50 \mathrm{ml})$. The organic layer was separated and the aqueous layer was extracted with $\mathrm{CH}_{2} \mathrm{Cl}_{2}(50 \mathrm{ml} \times 3)$. The combined extracts were washed with sat. $\mathrm{NaCl}$ and dried over anhyd. $\mathrm{Na}_{2} \mathrm{SO}_{4}$. After evaporation, the residue was subjected to MPLC (silica gel, $7 \%$ EtOAc in hexane) to affored $\mathbf{1 b}$ as an amorphous powder $(1.8 \mathrm{~g}, 67 \%) \cdot[\alpha]_{\mathrm{D}}^{25}+29.0^{\circ}\left(c=0.99, \mathrm{CHCl}_{3}\right)$. Mass $m / z: 380\left(\mathrm{M}^{+}\right)$. IR $v_{\max }^{\mathrm{KBr}} \mathrm{cm}^{-1}: 3380,1730,1620,1530$,
$1505,815,755 .{ }^{1} \mathrm{H}$ NMR $\delta: 3.7$ (broad s, $2 \mathrm{H},-\mathrm{NH}_{2}$ ), $6.7 \sim 8.2(\mathrm{~m}, 12 \mathrm{H}$, aromatic protones), 8.50 and $8.66(2 \times \mathrm{s}$, $1 \mathrm{H},-\mathrm{NHCO}-)$.

Preparation of the piperidino derivative 1c. To a mixture of $1 \mathrm{a}(2.0 \mathrm{~g}, 7.0 \mathrm{mmol}), \mathrm{DMF}(8 \mathrm{ml})$ and $\mathrm{CH}_{3} \mathrm{CN}(25 \mathrm{ml})$, an aqueous solution of glutaraldehyde $(25 \%, 2.8 \mathrm{ml}$, $7.0 \mathrm{mmol})$ and $\mathrm{NaBH}_{3} \mathrm{CN}(0.44 \mathrm{~g}, 7.0 \mathrm{mmol})$ were added with ice-cooling. The mixture was then stirred at room temperature for $2 \mathrm{hr}$, during which a solution of acetic acid $(1.3 \mathrm{~g}, 21 \mathrm{mmol})$ in $\mathrm{CH}_{3} \mathrm{CN}(5 \mathrm{ml})$ was added portionwise to maintain the $\mathrm{pH}$ around 7 . After stirring overnight, $3 \mathrm{~N}$ $\mathrm{HCl}(50 \mathrm{ml})$ was added and the acidic solution was washed with ether $(30 \mathrm{ml})$. The aqueous layer was made alkaline with $15 \% \mathrm{NaOH}$ and extracted with $\mathrm{CH}_{2} \mathrm{Cl}_{2}(50 \mathrm{ml} \times 3)$. The combined extracts were washed with sat. $\mathrm{NaCl}$ and dried over anhyd. $\mathrm{Na}_{2} \mathrm{SO}_{4}$. After evaporation, the residue was subjected to MPLC (silica gel, 14\% EtOAc in hexane) to afford 1c as an amorphous powder $(0.95 \mathrm{~g}, 38 \%)$. $[\alpha]_{\mathrm{D}}^{20}-12.3^{\circ}\left(c=1.97, \mathrm{CHCl}_{3}\right)$. Mass $m / z: 352\left(\mathrm{M}^{+}\right)$. IR $v_{\max }^{\mathrm{KBr}} \mathrm{cm}^{-1}: 3380,1620,1505,810,750 .{ }^{1} \mathrm{H}$ NMR $\delta:$ $0.9 \sim 1.5\left(\mathrm{~m}, 6 \mathrm{H},-\mathrm{CH}_{2} \mathrm{CH}_{2} \mathrm{CH}_{2}-\right), 2.8 \sim 3.1(\mathrm{~m}, 4 \mathrm{H}$, $\left.-\mathrm{N}\left(\mathrm{CH}_{2}-\right)_{2}\right), 3.7$ (broad s, $\left.2 \mathrm{H},-\mathrm{NH}_{2}\right), 6.9 \sim 8.1(\mathrm{~m}, 12 \mathrm{H}$, aromatic protones).

Preparation of the morpholino derivative 1d. Ozone gas was passed into a solution of 2,5-dihydrofuran $(1.12 \mathrm{~g}$, $16 \mathrm{mmol})$ in $\mathrm{MeOH}(25 \mathrm{ml})$ at $-60^{\circ} \mathrm{C}$ until a blue color developed. The excess ozone was expelled by passing argon gas at $-60^{\circ} \mathrm{C}$. $\mathrm{NaBH}_{3} \mathrm{CN}(3.0 \mathrm{~g}, 48 \mathrm{mmol})$ and a solution of $1 \mathrm{a}(4.3 \mathrm{~g}, 15 \mathrm{mmol})$ in DMF $(30 \mathrm{ml})$ were added at $-50^{\circ} \mathrm{C}$. The mixture was stirred with ice-cooling for $2.5 \mathrm{hr}$, during which acetic acid $(8.6 \mathrm{~g}, 0.14 \mathrm{~mol})$ was added portionwise to maintain the $\mathrm{pH}$ around 7. After evaporation, $5 \% \mathrm{NaOH}(50 \mathrm{ml})$ was added and the mixture was extracted with $\mathrm{CH}_{2} \mathrm{Cl}_{2}(50 \mathrm{ml} \times 3)$. The combined extracts were washed with sat. $\mathrm{NaCl}$ and dried over anhyd. $\mathrm{Na}_{2} \mathrm{SO}_{4}$. After evaporation, the residue was subjected to MPLC (silica gel, 3\% 2-propanol in hexane) to afford 1d as an amorphous powder $(2.3 \mathrm{~g}, 42 \%)$. $[\alpha]_{\mathrm{D}}^{20}-53.3^{\circ}\left(c=1.1, \mathrm{CHCl}_{3}\right)$. Mass $m / z: 354\left(\mathrm{M}^{+}\right)$. IR 
$v_{\max }^{\mathrm{KBr}} \mathrm{cm}^{-1}: 3360,1620,1510,820,750 .{ }^{1} \mathrm{H}$ NMR $\delta:$ $2.8 \sim 3.1 \quad\left(\mathrm{~m}, \quad 4 \mathrm{H}, \quad-\mathrm{N}\left(\mathrm{CH}_{2}-\right)_{2}\right), \quad 3.1 \sim 3.4 \quad(\mathrm{~m}, \quad 4 \mathrm{H}$, $\left.\left(-\mathrm{CH}_{2}\right)_{2} \mathrm{O}\right), 3.6$ (broad s, $\left.2 \mathrm{H},-\mathrm{NH}_{2}\right), 6.9 \sim 8.2(\mathrm{~m}, 12 \mathrm{H}$, aromatic protones).

Preparation of 2,4-dimethylglutaric anhydride 2 . The mixture of $c i$ and trans-isomers was prepared, and cis-2 was isolated according to Wiley. ${ }^{13)}$ The more soluble trans-2 was obtained as follows from the mother liquid from which $c i s-2$ was excluded. After hydrolyzing crude trans-2 in boiling water, the diacid was recrystallized from EtOAc three times (mp $140 \sim 141^{\circ} \mathrm{C}$ ). Treatment with acetic anhydride at $100^{\circ} \mathrm{C}$ for $1 \mathrm{hr}$ and distillation gave trans-7, bp $152 \sim 154^{\circ} \mathrm{C} / 20 \mathrm{mmHg},{ }^{1} \mathrm{H}$ NMR $\delta: 1.43$ (d, $\left.J=7.6 \mathrm{~Hz}, 6 \mathrm{H}, 2 \times \mathrm{CH}_{3}\right), 1.96\left(\mathrm{t}, J=6.6 \mathrm{~Hz}, 2 \mathrm{H},-\mathrm{CH}_{2}-\right)$, $2.7 \sim 3.1\left(\mathrm{~m}, 2 \mathrm{H}, 2 \times-\mathrm{C} \underline{\mathrm{H}}\left(\mathrm{CH}_{3}\right)-\right)$. The purity of each isomer was confirmed by GLC (temperature $120^{\circ} \mathrm{C}$ ).

Synthesis of $(2 R, 4 S)-2,4$-dimethyl- $\delta$-valerolactone $\mathbf{8}$. With 1c (Table I, run 2): cis-2,4-Dimethylglutaric anhydride (cis-2, $0.19 \mathrm{~g}, 1.3 \mathrm{mmol})$ was added to a solution of $1 \mathrm{c}(0.47 \mathrm{~g}, 1.3 \mathrm{mmol})$ in toluene $(15 \mathrm{ml})$ at $-20^{\circ} \mathrm{C}$. The mixture was allowed to stand at $-20^{\circ} \mathrm{C}$ for 3 days and then treated with an ethereal solution of diazomethane. To a solution of $7 \mathbf{b}$ in dry $\mathrm{EtOH}(10 \mathrm{ml}), \mathrm{LiCl}(0.17 \mathrm{~g}$, $3.9 \mathrm{mmol})$ and $\mathrm{NaBH}_{4}(0.15 \mathrm{~g}, 3.9 \mathrm{mmol})$ were added with ice-cooling. The mixture was heated at $50^{\circ} \mathrm{C}$ for $24 \mathrm{hr}$. After cooling, $3 \mathrm{~N} \mathrm{HCl}(20 \mathrm{ml})$ was added and the mixture was extracted with $\mathrm{CH}_{2} \mathrm{Cl}_{2}(30 \mathrm{ml} \times 3)$. The combined extracts were washed with sat. $\mathrm{NaCl}$, dried over anhyd. $\mathrm{Na}_{2} \mathrm{SO}_{4}$ and evaporated. $2 \mathrm{~N}$ Sulfuric acid $(20 \mathrm{ml})$ and dioxane $(4 \mathrm{ml})$ were added to the residue, and the mixture was heated at $80^{\circ} \mathrm{C}$ for $2 \mathrm{hr}$. After cooling, the solution was extracted with ether $(30 \mathrm{ml} \times 5)$. The combined extracts were washed successively with $3 \mathrm{~N} \mathrm{HCl}$ three times and sat. $\mathrm{NaCl}$, and then dried over anhyd. $\mathrm{Na}_{2} \mathrm{SO}_{4}$. Evaporation gave 8 as an oil $(0.16 \mathrm{~g}, 77 \%)$. An analytical sample was obtained with preparative GLC (column temperature, $\left.150^{\circ} \mathrm{C}\right) .[\alpha]_{\mathrm{D}}^{25}-37.8^{\circ}\left(c=1.3, \mathrm{CHCl}_{3}\right) 92 \%$ e.e.

With 1a (Table I, run 1): To a solution of $1 \mathrm{a}(1.0 \mathrm{~g}$, $3.5 \mathrm{mmol})$ in benzene $(35 \mathrm{ml})$, a solution of cis-2 $(0.65 \mathrm{~g}$, $4.6 \mathrm{mmol})$ in benzene $(15 \mathrm{ml})$ was added at room temperature. After stirring at room temperature overnight, diazomethane was added. The product was subjected to MPLC (silica gel, $20 \%$ EtOAc in hexane) to afford each diastereomer. $(2 S, 4 R)-7 \mathbf{a}(0.24 \mathrm{~g}, 15.5 \%)$, glass; $[\alpha]_{\mathrm{D}}^{25}-50.0^{\circ}\left(c=1.03, \mathrm{CHCl}_{3}\right)$; mass $m / z: 440\left(\mathrm{M}^{+}\right)$; ${ }^{1} \mathrm{H}$ NMR $(100 \mathrm{MHz}) \delta: 0.82$ and $0.96(2 \times \mathrm{d}, J=7.2 \mathrm{~Hz}$, $\left.6 \mathrm{H}, 2 \times \mathrm{CH}_{3}\right), 1.0 \sim 1.4,1.7 \sim 2.1$ and $2.2 \sim 2.5(\mathrm{~m}, 4 \mathrm{H}$, $\left.-\mathrm{C} \underline{\mathrm{H}}\left(\mathrm{CH}_{3}\right) \mathrm{C}_{2}{ }_{2} \mathrm{C}\left(\mathrm{CH}_{3}\right)-\right), 3.48\left(\mathrm{~s}, 3 \mathrm{H}, \mathrm{OCH}_{3}\right), \quad 3.8$ (broad s, $\left.2 \mathrm{H}, \quad-\mathrm{NH}_{2}\right), \quad 6.8 \sim 8.0(\mathrm{~m}, 12 \mathrm{H}$, aromatic protones), 8.43 and $8.52(2 \times \mathrm{s}, 1 \mathrm{H},-\mathrm{NHCO}-)$. $(2 R, 4 S)-7 \mathbf{a}$ $\left(0.69 \mathrm{~g}, 44.5^{\circ}\right), \mathrm{mp} 149 \sim 150^{\circ} \mathrm{C} ;[\alpha]_{\mathrm{D}}^{25}-52.6^{\circ} \quad(c=1.07$, $\left.\mathrm{CHCl}_{3}\right)$; mass $m / z: 440\left(\mathrm{M}^{+}\right) ;{ }^{1} \mathrm{H}$ NMR $(100 \mathrm{MHz}) \delta: 0.77$ and $0.94\left(2 \times \mathrm{d}, J=7.2 \mathrm{~Hz}, 2 \times \mathrm{CH}_{3}\right), 1.1 \sim 1.3$ and $1.5 \sim 2.4$ (m, $\left.4 \mathrm{H},-\mathrm{C} \underline{\mathrm{H}}\left(\mathrm{CH}_{3}\right) \mathrm{CH}_{2} \mathrm{C} \underline{\mathrm{H}}\left(\mathrm{CH}_{3}\right)-\right), 3.4$ (broad s, $2 \mathrm{H}$, $\left.-\mathrm{NH}_{2}\right), 3.51\left(\mathrm{~s}, 3 \mathrm{H}, \mathrm{OCH}_{3}\right), 6.8 \sim 8.1(\mathrm{~m}, 12 \mathrm{H}$, aromatic protones), 8.50 and $8.59(2 \times \mathrm{s}, 1 \mathrm{H},-\mathrm{NHCO}-)$.

Acetic anhydride $(0.29 \mathrm{~g}, 2.8 \mathrm{mmol})$ and triethylamine $(0.28 \mathrm{~g}, 2.8 \mathrm{mmol})$ were added to a solution of $(2 R, 4 S)-7 \mathbf{a}$ $(0.60 \mathrm{~g}, 1.4 \mathrm{mmol})$ in $\mathrm{CH}_{2} \mathrm{Cl}_{2}(5 \mathrm{ml})$ at $0^{\circ} \mathrm{C}$. The mixture was stirred at room temperature overnight. After adding sat. $\mathrm{NaHCO}_{3}(10 \mathrm{ml})$, the mixture was extracted with $\mathrm{CH}_{2} \mathrm{Cl}_{2}(20 \mathrm{ml} \times 3)$. The combined extracts were washed with sat. $\mathrm{NaCl}$ and dried over anhyd. $\mathrm{Na}_{2} \mathrm{SO}_{4}$. Evaporation gave the acetylated $7 \mathrm{a}(0.63 \mathrm{~g})$. This product was reduced and hydrolyzed according to the previous procedure to afford $8\left(0.08 \mathrm{~g}, 46^{\circ} \%\right),[\alpha]_{\mathrm{D}}^{25}-42.4^{\circ}$.

Synthesis of $(R)$-mevalonolactone 9 . To a solution of 3 hydroxy-3-methylglutaric anhydride $(3,0.29 \mathrm{~g}, 2.0 \mathrm{mmol})$ in $\mathrm{CH}_{2} \mathrm{Cl}_{2}(30 \mathrm{ml}), \mathbf{1 d}(0.79 \mathrm{~g}, 2.0 \mathrm{mmol})$ was added at $-20^{\circ} \mathrm{C}$. The mixture was allowed to stand at $-20^{\circ} \mathrm{C}$ for 7 days. After treating with diazomethane, the amide-ester $7 \mathbf{e}$ was reduced as described in the synthesis of $\mathbf{8}$ from $\mathbf{7 b}$. After working up, alkaline hydrolysis was carried out using $10 \% \mathrm{KOH}$ in $\mathrm{MeOH}(20 \mathrm{ml})$ at $60^{\circ} \mathrm{C}$ for $4 \mathrm{hr}$. After neutralizing with $2 \mathrm{~N} \mathrm{H}_{2} \mathrm{SO}_{4}, \mathrm{MeOH}$ was distilled off under reduced pressure. The aqueous solution was continuously extracted with ether at $\mathrm{pH} 3.0$ for 3 days. The extract was dried over anhyd. $\mathrm{Na}_{2} \mathrm{SO}_{4}$ and evaporated. The residue was subjected to preparative TLC (silica gel, $33 \%$ EtOAc in benzene) to afford $9(0.11 \mathrm{~g}, 44 \%)$, $[\alpha]_{\mathrm{D}}^{25}-12.2^{\circ}(c=6.0, \mathrm{EtOH})$. Determination of the e.e. of 9 was performed with ${ }^{1} \mathrm{H}$ NMR $(400 \mathrm{MHz})$ according to Wilson. ${ }^{18)}$ Peak separation was observed at a proton adjacent to the carbonyl group; $9(30.4 \mathrm{mg})$ and $\mathrm{Eu}(\mathrm{hfc})_{3}$ $(45.0 \mathrm{mg})$ in $\mathrm{CDCl}_{3}(680 \mathrm{mg})$.

Synthesis of (R)-3-isopropyl- $\delta$-valerolactone 10 . To a solution of $\mathbf{1 b}(0.5 \mathrm{~g}, 1.3 \mathrm{mmol})$ in toluene $(10 \mathrm{ml}), 3-$ isopropylglutaric anhydride $(4,0.23 \mathrm{~g}, 1.5 \mathrm{mmol})$ was added at room temperature. After stirring overnight, diazomethane was added. By the same treatment for the synthesis of $\mathbf{8}$ from $\mathbf{7 b}$, the amide-ester $7 \mathbf{f}$ was converted to $10(0.05 \mathrm{~g}, 38 \%),[\alpha]_{\mathrm{D}}^{25}+7.1^{\circ}(c=0.83, \mathrm{EtOH})$. The amideester $7 \mathbf{f}$ was separated into each diastereomer with MPLC (silica gel, $12 \%$ EtOAc in hexane). (3S)-7f, glass; $[\alpha]_{\mathrm{D}}^{25}-57.8^{\circ}\left(c=0.54, \mathrm{CHCl}_{3}\right)$; mass $m / z: 550\left(\mathrm{M}^{+}\right) ;{ }^{1} \mathrm{H}$ NMR $(400 \mathrm{MHz}) \delta: 0.61\left(2 \times \mathrm{d}, J=6.8 \mathrm{~Hz}, 6 \mathrm{H}, 2 \times \mathrm{CH}_{3}\right)$, $1.19 \sim 1.29\left(\mathrm{~m}, 1 \mathrm{H},-\mathrm{C} \underline{\mathrm{H}}\left(\mathrm{CH}_{3}\right)_{2}\right), 1.66 \sim 1.74,1.76 \sim 1.84$ and $2.08 \sim 2.13\left(\mathrm{~m}, 5 \mathrm{H},-\mathrm{CH}\left(\mathrm{CH}_{2}-\right)_{2}\right), 3.47\left(\mathrm{~s}, 3 \mathrm{H}, \mathrm{OCH}_{3}\right)$, $7.04 \sim 8.74^{\circ}(\mathrm{m}, \quad 14 \mathrm{H}, \quad 2 \times-\mathrm{CONH}-$ and aromatic protones). (3R)-7f, glass; $[\alpha]_{\mathrm{D}}^{25}-73.8^{\circ}\left(c=1.01, \mathrm{CHCl}_{3}\right)$; mass $m / z: 550\left(\mathrm{M}^{+}\right) ;{ }^{1} \mathrm{H}$ NMR $(400 \mathrm{MHz}) \delta: 0.52$ and 0.66 $\left(2 \times \mathrm{d}, J=6.8 \mathrm{~Hz}, \quad 6 \mathrm{H}, 2 \times \mathrm{CH}_{3}\right), 1.07 \sim 1.15(\mathrm{~m}, 1 \mathrm{H}$, $\left.-\mathrm{CH}\left(\mathrm{CH}_{3}\right)_{2}\right), \quad 1.66 \sim 1.77$ and $1.96 \sim 2.12(\mathrm{~m}, 5 \mathrm{H}$, $\left.-\mathrm{CH}\left(\mathrm{CH}_{2}-\right)_{2}\right), 3.51\left(\mathrm{~s}, 3 \mathrm{H}, \mathrm{OCH}_{3}\right), 7.05 \sim 8.55(\mathrm{~m}, 14 \mathrm{H}$, $2 \times-\mathrm{CONH}-$ and aromatic protones).

Synthesis of (2R,3S)-2,3-methylene- $\gamma$-butyrolactone 11. To a solution of $\mathbf{1 b}(1.14 \mathrm{~g}, 3.0 \mathrm{mmol})$ in toluene $(15 \mathrm{ml})$, 1,2-cyclopropanedicarboxylic anhydride $(\mathbf{5}, \quad 0.4 \mathrm{~g}$, $3.6 \mathrm{mmol}$ ) was added at room temperature. After stirring 
overnight, diazomethane was added. By the same treatment as described in the synthesis of $\mathbf{8}$ from $\mathbf{7 b}$, the amide-ester $\mathbf{7 g}$ was converted to $11(0.19 \mathrm{~g}, 65 \%)$. $[\alpha]_{\mathrm{D}}^{25}+28.0^{\circ}\left(c=6.41, \mathrm{CHCl}_{3}\right)$.

The ring opening reaction of cis-1,2-cyclohexanedicarboxylic anhydride $\mathbf{6}$ with 1a. To a solution of 1a $(0.5 \mathrm{~g}, 1.75 \mathrm{mmol})$ in benzene $(15 \mathrm{ml}), 6(0.27 \mathrm{~g}, 1.75$ $\mathrm{mmol}$ ) was added at room temperature. Stirring was continued at room temperature for $72 \mathrm{hr}$ and diazomethane was added. Evaporation gave a diastereoisomeric mixture of $\mathbf{7 h}$, and this was subjected to MPLC (silica gel, 10\% EtOAc in hexane). The isomer eluting faster $(0.08 \mathrm{~g}, 10 \%)$, glass; $[\alpha]_{\mathrm{D}}^{25}-30.3^{\circ}\left(c=1.03, \mathrm{CHCl}_{3}\right)$; mass $m / z$ : $452\left(\mathrm{M}^{+}\right) ;{ }^{1} \mathrm{H}$ NMR $(100 \mathrm{MHz}) \delta: 0.8 \sim$ $2.1\left(\mathrm{~m}, 8 \mathrm{H},-\left(\mathrm{CH}_{2}\right)_{4}-\right), 2.3 \sim 2.6$ and $2.6 \sim 2.9(\mathrm{~m}, 2 \mathrm{H}$, - $\mathrm{COC}{ }^{\prime} \mathrm{HCHCO}^{\prime}$ ), 3.5 (broad s, $\left.2 \mathrm{H},-\mathrm{NH}_{2}\right), 3.52(\mathrm{~s}, 3 \mathrm{H}$, $\left.\mathrm{OCH}_{3}\right), 6.8 \sim 8.0(\mathrm{~m}, 12 \mathrm{H}$, aromatic protones), 8.52 and $8.61(2 \times \mathrm{s}, 1 \mathrm{H},-\mathrm{NHCO}-)$. The isomer eluting slower $(0.18 \mathrm{~g}, 22 \%), \mathrm{mp} 165 \sim 166^{\circ} \mathrm{C} ; \quad[\alpha]_{\mathrm{D}}^{25}-28.7^{\circ} \quad(c=1.35$, $\left.\mathrm{CHCl}_{3}\right)$; mass $m / z$ : $452\left(\mathrm{M}^{+}\right) ;{ }^{1} \mathrm{H}$ NMR $(100 \mathrm{MHz}) \delta$ : $0.8 \sim 2.1 \quad\left(\mathrm{~m}, \quad 8 \mathrm{H}, \quad-\left(\mathrm{CH}_{2}\right)_{4}-\right), 2.4 \sim 2.7 \quad(\mathrm{~m}, \quad 2 \mathrm{H}$, - $\mathrm{COCHCHCO}-$ ), 3.5 (broad s, $2 \mathrm{H},-\mathrm{NH}_{2}$ ), $3.48(\mathrm{~s}, 3 \mathrm{H}$, $\left.\mathrm{OCH}_{3}\right), 6.8 \sim 8.0(\mathrm{~m}, 12 \mathrm{H}$, aromatic protones), 8.52 and $8.62(2 \times \mathrm{s}, 1 \mathrm{H},-\mathrm{NHCO}-)$.

Synthesis of $(2 R, 4 R)$-dimethyl- $\delta$-valerolactone $\mathbf{1 2}$ through kinetic resolution. To a solution of $1 \mathrm{c}(0.53 \mathrm{~g}$, $1.5 \mathrm{mmol})$ in toluene $(25 \mathrm{ml})$, trans $-2(1.1 \mathrm{~g}, 7.5 \mathrm{mmol})$ was added at $-20^{\circ} \mathrm{C}$. After stirring at $-20^{\circ} \mathrm{C}$ for 2 days, diazomethane was added. After expelling the excess diazomethane, the solution was treated with propylamine $(0.47 \mathrm{~g}, 7.9 \mathrm{mmol})$ at room temperature for $1 \mathrm{hr}$. The mixture was washed with sat. $\mathrm{NaHCO}_{3}$ three times and dried over anhyd. $\mathrm{Na}_{2} \mathrm{SO}_{4}$. Evaporation gave the amideester $\mathbf{7 b}$, which was reduced and hydrolyzed as described for the cis counterpart of $\mathbf{7 b}$. Distillation gave $12(0.09 \mathrm{~g}$, $47 \%)$, bp $135^{\circ} \mathrm{C} / 15 \mathrm{mmHg}$. $[\alpha]_{\mathrm{D}}^{20}-60.1^{\circ}\left(c=2.13, \mathrm{CHCl}_{3}\right)$. The ${ }^{1} \mathrm{H}$ NMR spectrum $(400 \mathrm{MHz})$ is depicted in Fig. 1.

The trans lactone 12 was also yielded using 1d according to this same procedure in a yield of $41 \% \cdot[\alpha]_{\mathrm{D}}^{20}-53.4^{\circ}$ $\left(c=1.9, \mathrm{CHCl}_{3}\right)$.

\section{REFERENCES}

1) A preliminary communication on this subject has appeared: Y. Kawakami, J. Hiratake, Y. Yamamoto and J. Oda, J. Chem. Soc., Chem. Commun., 779 (1984)

2) S. Terashima and S. Yamada, Tetrahedron Lett., 1001 (1977); S. Terashima, M. Nara and S. Yamada, Tetrahedron Lett., 1487 (1978).
3) I. J. Jakovac, H. B. Goodbrand, K. P. Lok and J. B. Jones, J. Am. Chem. Soc., 104, 4659 (1982).

4) F.-C. Huang, L. F. Hsu Lee, R. S. D. Mittal, P. R. Revikumar, J. A. Chan and C. J. Sih, J. Am. Chem. Soc., 97, 4144 (1975); K. Laumen, E. H. Reimerdes and M. Schneider, Tetrahedron Lett., 26, 407 (1985), and references cited therein.

5) Y. Nagao, T. Ikeda, M. Yagi and E. Fujita, J. Am. Chem. Soc., 104, 2079 (1982).

6) Y. Aoki, H. Suzuki, H. Akiyama and S. Okano, Jap. P. Appl., 72 63, 03222 June 1978, 39 pp; T. Mukaiyama, H. Yamashita and M. Asami, Chem. Lett., 385 (1983); K. Osakada, M. Obana, T. Ikariya, S. Saburi and S. Yoshikawa, Tetrahedron Lett., 22, 4297 (1981); Y. Ishii, K. Osakada, T. Ikariya, M. Saburi and S. Yoshikawa, Chem. Lett., 1179 (1982).

7) P. S. Schwartz and H. E. Carter, Proc. Natl. Acad. Sci., U.S.A., 40, 499 (1954).

8) R. Altschul, P. Berstein and S. G. Cohen, J. Am. Chem. Soc., 78, 5091 (1956).

9) For recent reports on the opening of prochiral acid anhydrides with chiral alcohols, see U. Salz and C. Rüchardt, Chem. Ber., 117, 3457 (1984); T. Rosen and C. H. Heathcock, J. Am. Chem. Soc., 107, 3731 (1985).

10) G. R. Clemo and E. C. Dawson, J. Chem. Soc., 1114 (1939); R. Kuhn and P. Goldfinger, Liebigs Ann. Chem., 470, 183 (1929).

11) Recently, the diamine 1a was employed for chiral lithium aluminum hydride complexes; see $\mathrm{K}$. Kabuto, T. Yoshida, S. Yamaguchi, S. Miyano and H. Hashimoto, J. Org. Chem., 50, 3013 (1985).

12) M. Kawaguchi, J. Ohashi, Y. Kawakami, Y. Yamamoto and J. Oda, Synthesis, 701 (1985).

13) P. F. Wiley, K. Gerzon, E. H. Flynn, M. V. Sigal, Jr., O. Weaver, U. C. Quarck, R. R. Chauvette and R. Monahan, J. Am. Chem. Soc., 79, 6062 (1957).

14) IR and ${ }^{1} \mathrm{H}$ NMR spectra substantiated the proposed structures of all the lactones described here.

15) P. Lewer and J. MacMillan, J. Chem. Soc., Perkin Trans. 1, 1417 (1983).

16) J. N. Edmund and J. F. Thorpe, J. Chem. Soc., 117, 1465 (1920).

17) A. Wassermann, Helv. Chim. Acta, 13, 223 (1930).

18) W. K. Wilson, T. J. Scallen and C. J. Morrow, J. Lipid Res., 23, 645 (1982).

19) For the theoretical treatment of the kinetic resolution, see Y. Kawakami, J. Hiratake, Y. Yamamoto and J. Oda, Bull. Inst. Chem. Res. Kyoto Univ., 63, 100 (1985).

20) F. I. Carroll and J. T. Blackwell, Tetrahedron Lett., 4173 (1970); F. I. Carroll, A. Sobti and R. Meck, Tetrahedron Lett., 405 (1971). 